U.S. Department of the Interior U.S. Geological Survey

\title{
Natural Gemstones
}




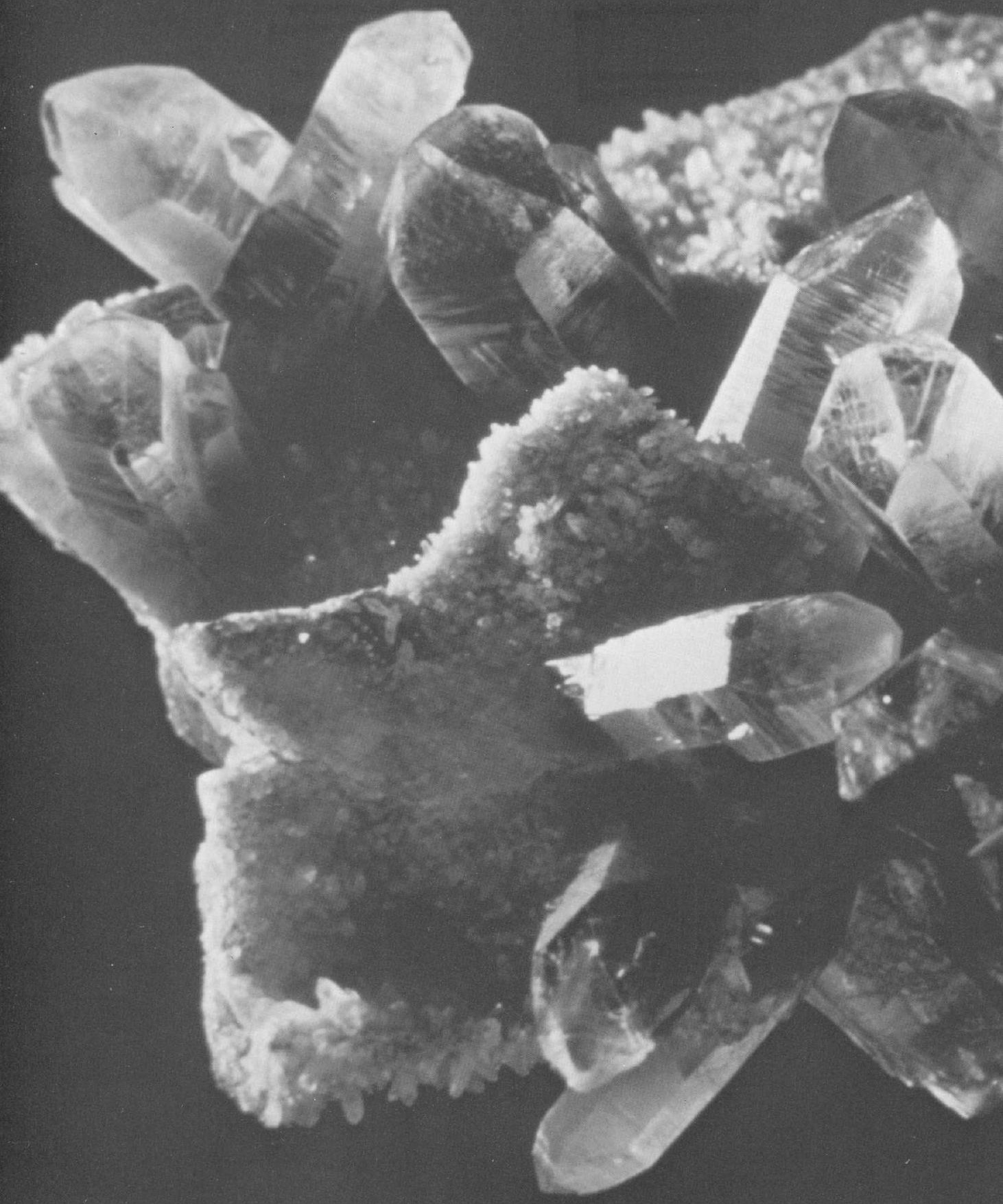


U.S. Department of the Interior

U.S. Geological Survey

\section{Natural Gemstones}

Searching for gemstones in the United States is a popular recreational activity for collectors and hobbyists 


\section{Natural gemstones}

A natural gemstone is a mineral, stone, or organic matter that can be cut and polished or otherwise treated for use as jewelry or other ornament. A precious gemstone has beauty, durability, and rarity, whereas a semiprecious gemstone has only one or two of these qualities. A gem is a gemstone that has been cut and polished.

Diamond, corundum (ruby and sapphire), beryl (emerald and aquamarine), topaz, and opal are generally classed as precious stones. All other gemstones are usually classed as semiprecious.

A mineral is any naturally formed homogeneous inorganic material.

A mineralogist is a person who studies the formation, occurrence, properties, composition, and classification of minerals.

A gemologist is a person who has successfully completed recognized courses in gemology (the science and study of gemstones) and has proven skills in identifying and evaluating gem materials.

A lapidary is a cutter, polisher, or engraver of precious stones.

\section{Geologic environment}

Gemstones are not plentiful. Gemstones do not form "ore" deposits in the normal sense.

Gems, when present at all, tend to be scattered sparsely throughout a large body of rock or to have crystallized as small aggregates or fill veins and small cavities.

Even stream gravel concentrations tend to be small-a few stones in each of several bedrock cracks, potholes, or gravel lenses in a stream bed.
The average grade of the richest diamond kimberlite pipes in Africa is about 1 part diamond in 40 million parts "ore."

Kimberlite, a plutonic igneous rock, ascends from a depth of at least 100 kilometers (60 miles) to form a diatreme (narrow cone-shaped rock body or "pipe"). Moreover, because much diamond is not of gem quality, the average stone in an engagement ring is the product of the removal and processing of 200 to 400 million times its volume of rock.

\section{Gemstones occur in most major geologic environments.}

Each environment tends to have a characteristic suite of gem materials, but many kinds of gems occur in more than one environment. Most gemstones are found in igneous rocks and alluvial gravels, but sedimentary and metamorphic rocks may also contain gem materials.

Examples of geologic environments in which gemstones are found:

Pegmatite-a coarse-grained intrusive igneous rock body, occurring as dikes (a tabular-shaped body), lenses, or veins in the surrounding rock.

Stream gravels (placers)-deposits of heavier and more durable than average minerals that have been eroded out of the original rock. Often tourmaline, beryl, and many other gem-quality minerals have eroded out of the original rock in which they formed and have moved and been concentrated locally by water in streams. Sapphires in Judith Basin County, Montana, were first found when the gravels were worked for gold from 1895 to 1930.

Metamorphic rocks-rocks that have been altered by great heat, pressure, or both. Garnet, for example, is commonly found as crystals in gneiss and mica schist. 


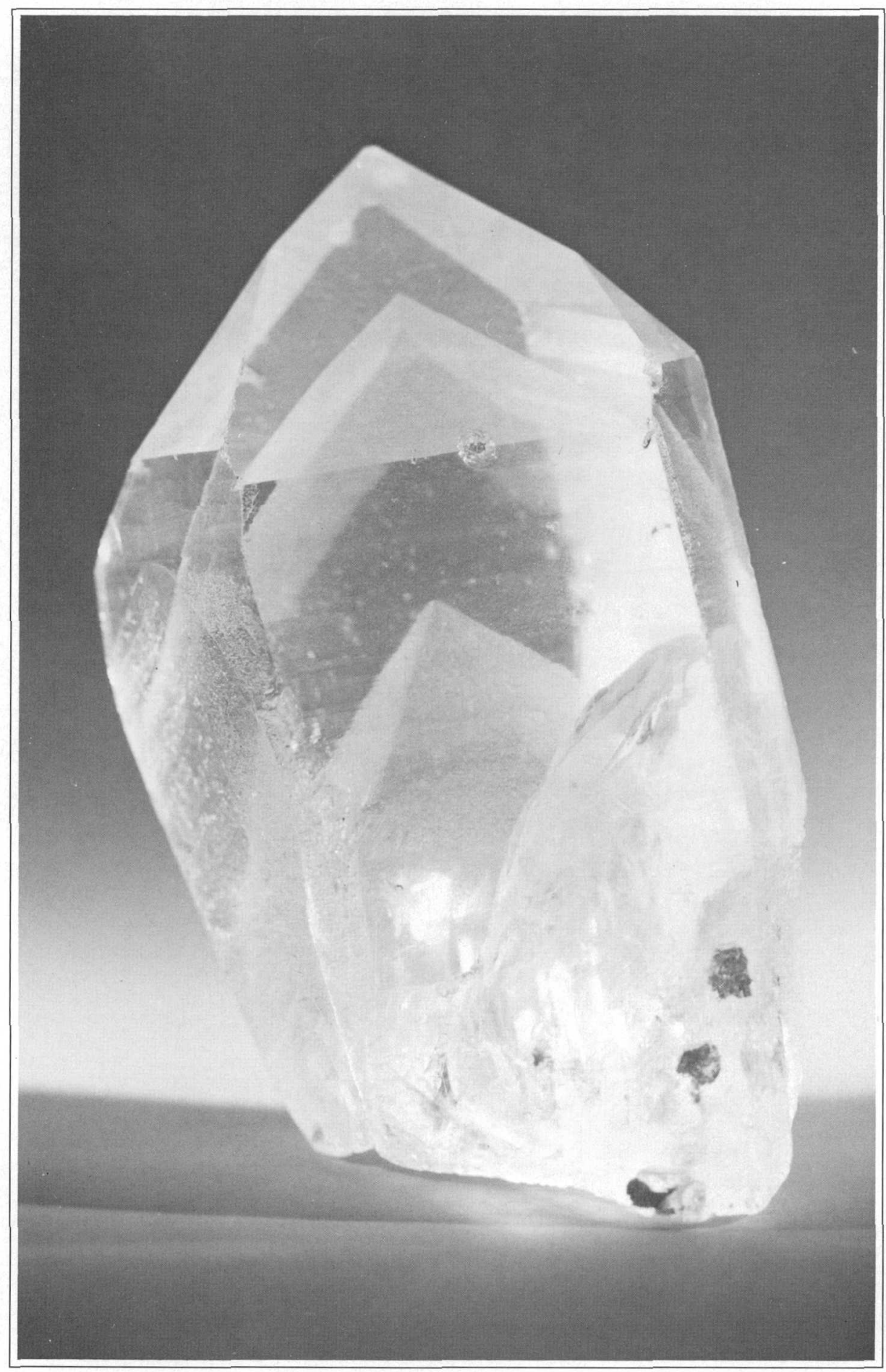

Quartz with phantoms, Brazil. 


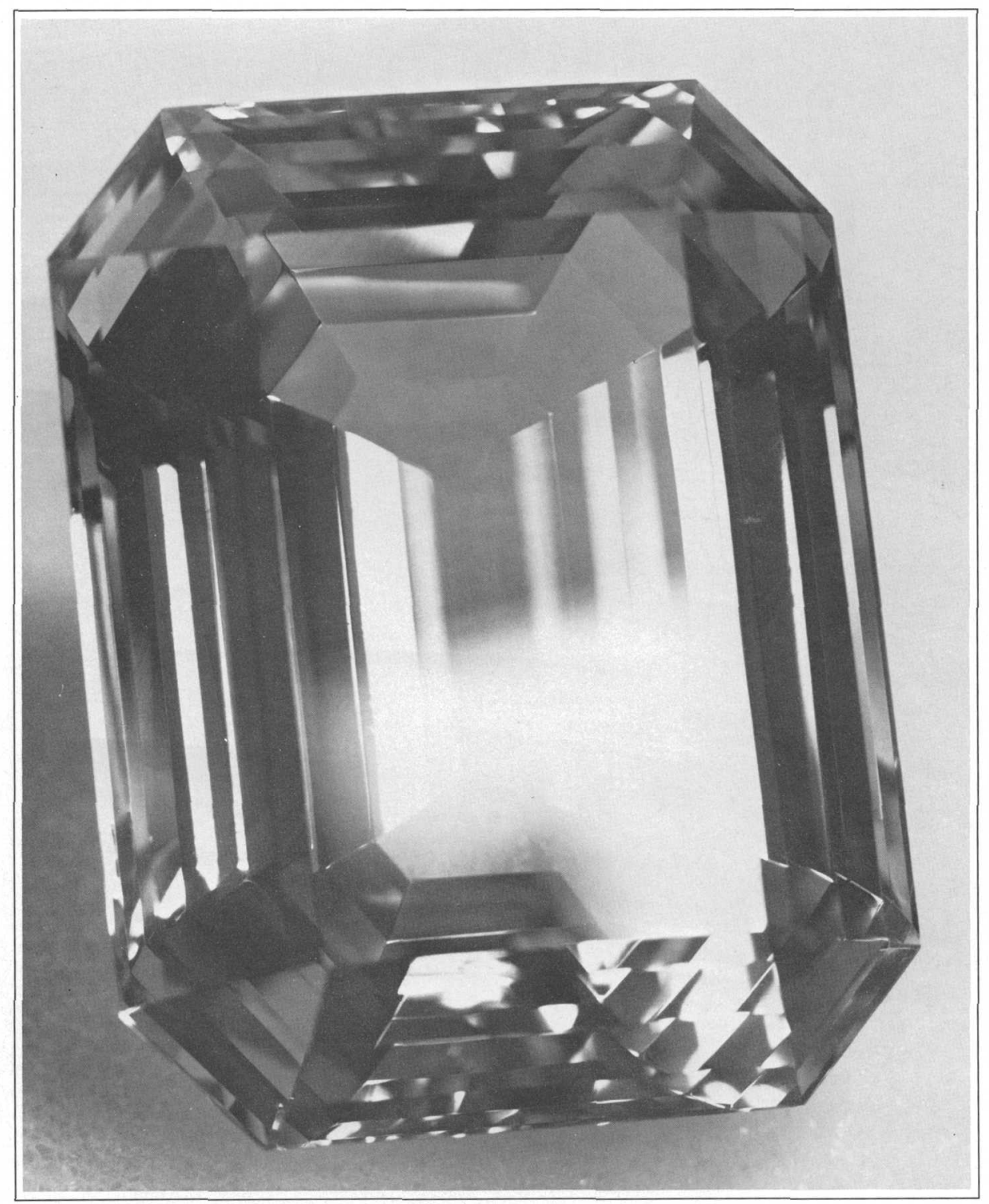

Aquamarine, Brazil. 


\section{Mineral gemstones}

Hardness and specific gravity are two of the major characteristics of gemstones.

Hardness of a gemstone is its resistance to scratching and may be described relative to a standard scale of 10 minerals known as the Mohs scale. F. Mohs, an Austrian mineralogist, developed this scale in 1822 .

According to Mohs' scale, the hardness ofTalc is 1 Feldspar is 6

Gypsum is 2 Quartz is 7

Calcite is 3 Topaz is 8

Fluorite is 4 Sapphire is 9

Apatite is 5

Diamond is 10

Specific gravity is the number of times heavier a gemstone of any volume is than an equal volume of water; in other words, it is the ratio of the density of the gemstone to the density of water.

The 16 mineral gemstone groups listed below are highly prized for their beauty, durability, and rarity:

Beryl (hardness: 7.5-8 Mohs)

Beryllium aluminum silicate

Specific gravity: 2.63-2.91

Emerald: Intense green or bluish green Aquamarine: Greenish blue or light blue Morganite: Pink, purple pink, or peach Heliodore: Golden yellow to golden green Red beryl: Raspberry red Goshenite: Colorless, greenish yellow, yellow green, brownish

Chrysoberyl (hardness: 8.5 Mohs)

Beryllium aluminum oxide

Specific gravity: $3.68-3.78$

Chrysoberyl: transparent yellowish green to greenish yellow and pale brown

Alexandrite: red in incandescent light and green in daylight

Cat's eye: usually yellowish or greenish
Corundum (hardness: 9 Mohs)

Aluminum oxide

Specific gravity: $3.96-4.05$

Ruby: Intense red

Sapphire: Blue

Diamond (hardness: 10 Mohs)

Carbon

Specific gravity: 3.51

Colorless to faint yellowish tinge, also variable

Feldspar (hardness: 6-6.5 Mohs)

Two distinctly different alkali alumino silicates: the Plagioclase and the Alkali Feldspar Series

Specific gravity: $2.55-2.76$

Plagioclase Series-

Labradorite: Colorful, iridescent, also transparent stones in yellow, orange, red, and green

Sunstone: Gold spangles from inclusions of hematite

Peristerite: Blue white iridescence

Alkali Feldspar Group-

Orthoclase: Pale yellow, flesh red

Amazonite: Yellow green to greenish blue Mounstone: Colorless; also white to yellowish, and reddish to bluish gray

Garnet (hardness: 6.5-7.5 Mohs)

A group of silicate minerals

Specific gravity: $3.5-4.3$

Almandine: Orangy red to purplish red Almandine-spessartine: Reddish orange Andradite: Yellowish green to orangy yellow to black

Demantoid: Green to yellow green andradite

Topazolite: Yellow to orangy yellow Grossular: Colorless; also orange, pink, yellow, and brown

Tsavorite: Green to yellowish green

Hessonite: Yellow orange to red

Pyrope: Colorless; also pink to red

Chrome pyrope: Orange red 
Pyrope-Almadine: Reddish orange to red purple

Pyrope-Spessartine: Greenish yellow to purple

Malaia: Yellowish to reddish orange to brown

Color-change garnet: Blue green in daylight to purple red in incandescent light

Rhodolite: Purplish red to red purple

Spessartine: Yellowish orange

Uvarovite: Emerald green

Jade (hardness: 6 Mohs)

Nephrite

Calcium magnesium silicate

Specific gravity: 2.9-3.1

White, deep green, creamy brown

\section{Jadeite}

Sodium aluminum silicate

Specific gravity: 3.1-3.5

White, leafy and blue green, emerald green, lavender, dark blue green and greenish black, deep emerald-green

Lapis lazuli (hardness: 5-5.5 Mohs)

A rock composed mainly of the mineral

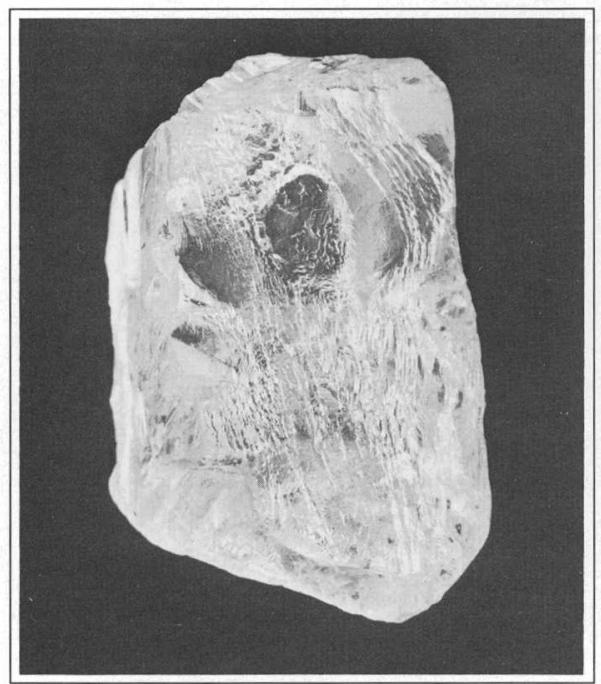

Diamond Star of Sierra Leone. lazurite with variable amounts of pyrite (brassy flecks) and white calcite

Specific gravity: 2.7-2.9

Deep blue, azure blue, greenish blue (bluish color with flecks of white and gold)

Opal (hardness: 5.5-6.5 Mohs)

Hydrated silica

Specific gravity: 1.98-2.25

White opal: Opaque, porcelain-like white material; colors resemble flashes or speckles

Black opal: Flashes and speckles appear against black background

Water opal: A transparent, colorless opal is the background for brilliant flashes of color

Fire opal: Reddish or orange opal

Peridot [Olivine] (hardness: 7 Mohs)

Magnesium iron silicate

Specific gravity: 3.22-3.45

Olive to lime green

Quartz (hardness: 7 Mohs)

Silicon dioxide or silica

Specific gravity: 2.65

Coarsely crystalline varieties of silicaRock crystal: Colorless

Amethyst: Purple

Citrine: Yellow to amber

Morion: Black

Smoky quartz or cairngorm: smoky gray to brown

Rose quartz: Translucent pink

Green quartz or praziolite: Green

Cryptocrystalline varieties of silicaChalcedony and Jasper (variable)

Agate: Bull's eye agate, Iris or fire agate, Onyx, Sardonyx. Bloodstone or heliotrope. Carnelian. Chrysoprase. Moss agate.

Plasma. Prase. Sard. Jasper.

Spinel (hardness: 8 Mohs)

Magnesium aluminum oxide

Specific gravity: $3.58-4.06$ 


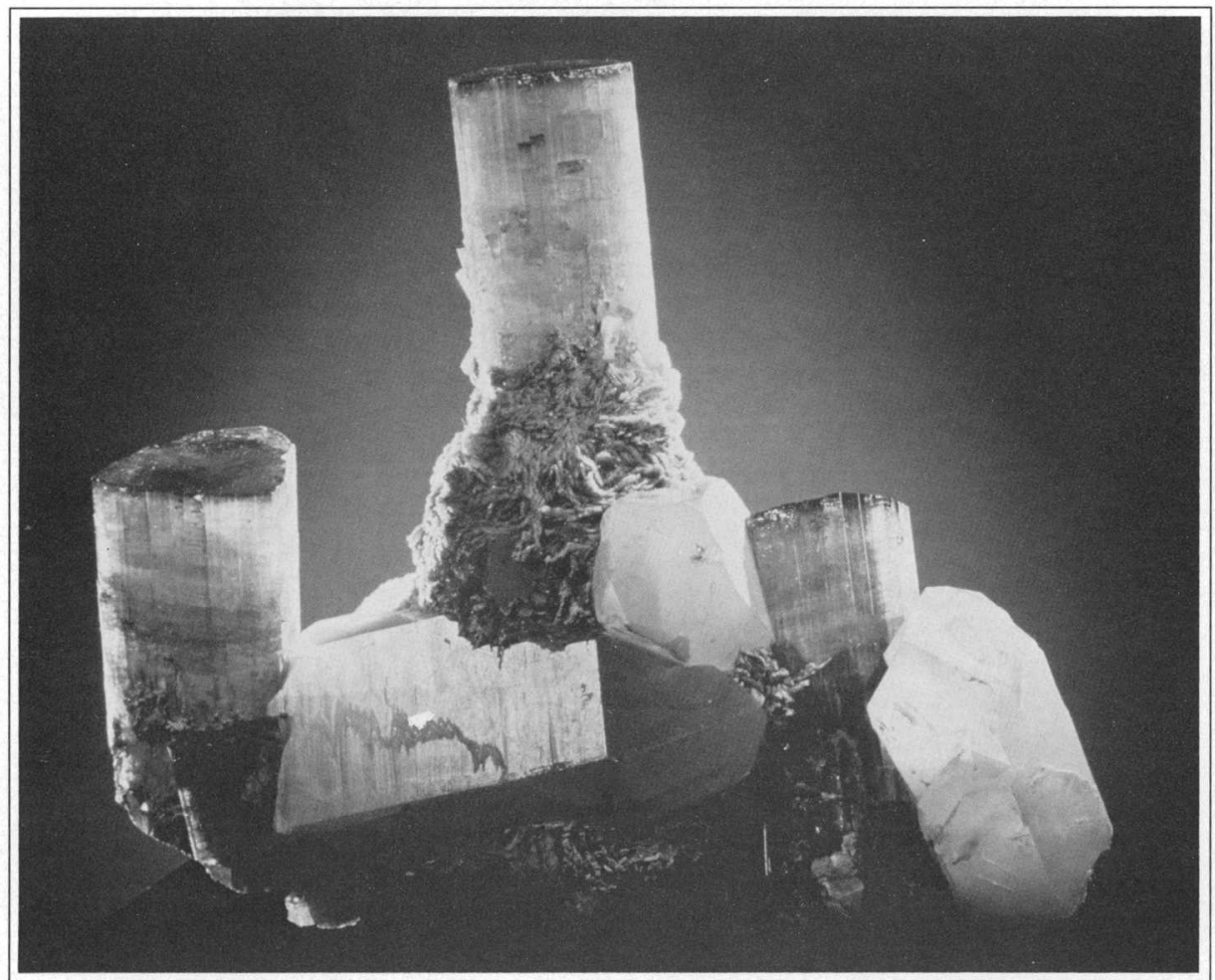

Candelabra: white quartz, blue-capped red elbaite, and tan albite, California.

Balas ruby: Red

Almandine spinel: Purple red

Rubicelle: Orange

Sapphire spinel and ghanospinel: Blue

Chlorspinel: Green

Topaz (hardness: 8 Mohs)

Aluminum silicate fluoride hydroxide

Specific gravity: $3.5-3.6$

Wine yellow, pale blue, green, violet, or red

Tourmaline (hardness: 7-7.5 Mohs)

Complex aluminum borosilicate

(Elbaite, Dravite, Uvite)

Specific gravity: 3.03-3.25

Achorite: Colorless

Brazilian emerald: Green

Dravite: Brown
Indicolite: Dark blue

Rubellite: Pink to red

Siberite: Violet

Verdilite: Green

Turquoise (hardness: 5-6 Mohs)

Hydrous copper aluminum phosphate

Specific gravity: 2.6-2.8

Sky blue; greenish blue

Zircon (hardness: 7.5 Mohs)

Zirconium silicate

Specific gravity: 4.6-4.7

Jargon: Variable

Matura diamond: Colorless

Hyacinth: Yellow, orange, red, brown 


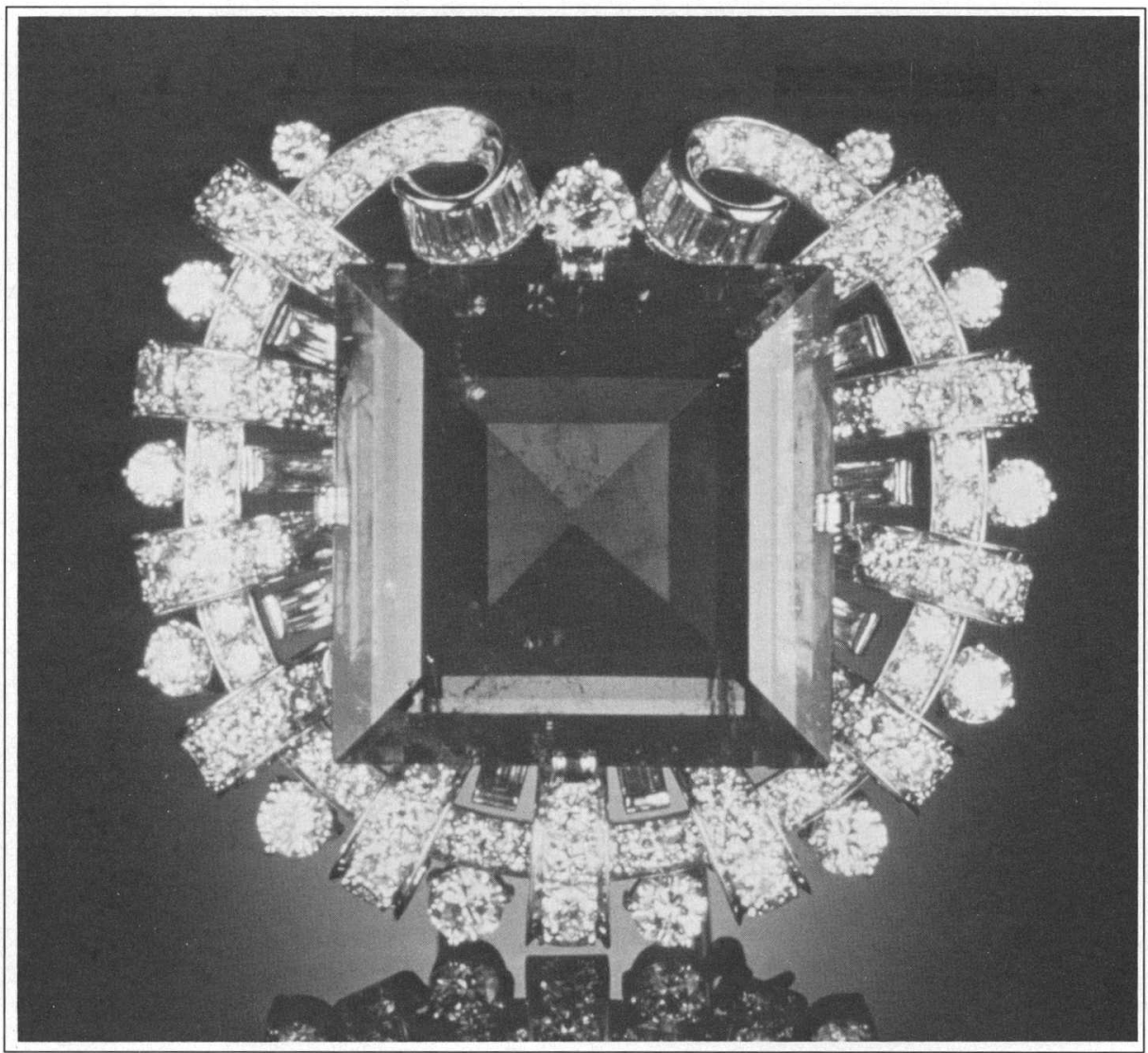

The Hooker Emerald, Colombia.

\section{Birthstones}

\begin{tabular}{|c|c|c|c|c|c|}
\hline $\begin{array}{l}\text { Month } \\
\text { of birth }\end{array}$ & Gemstone & Color & $\begin{array}{l}\text { Month } \\
\text { of birth }\end{array}$ & Gemstone & Color \\
\hline January & Garnet & Dark red & \multirow[t]{3}{*}{ July } & \multirow{3}{*}{$\begin{array}{l}\text { Ruby (Corundum) } \\
\text { or Carnelian } \\
\text { (Quartz) }\end{array}$} & \multirow[t]{3}{*}{ Red } \\
\hline February & Amethyst (Quartz) & Purple & & & \\
\hline \multirow[t]{2}{*}{ March } & Aquamarine (Beryl) & \multirow[t]{2}{*}{ Pale blue } & & & \\
\hline & $\begin{array}{l}\text { or Bloodstone } \\
\text { (Quartz) }\end{array}$ & & August & $\begin{array}{l}\text { Peridot } \\
\text { or Sardonyx } \\
\text { (Quartz) }\end{array}$ & $\begin{array}{l}\text { Pale green } \\
\text { Brown } \\
\text { and white }\end{array}$ \\
\hline \multirow[t]{2}{*}{ April } & Diamond or & \multirow[t]{2}{*}{ Colorless } & September & $\begin{array}{l}\text { (Quartz) } \\
\text { Sapphire }\end{array}$ & Pale to dark \\
\hline & (Quartz) & & & (Corundum) & blue \\
\hline \multirow[t]{2}{*}{ May } & \multirow{2}{*}{$\begin{array}{l}\text { Emerald (Beryl) } \\
\text { or Chrysoprase } \\
\text { (Quartz) }\end{array}$} & \multirow{2}{*}{$\begin{array}{l}\text { Bright green } \\
\text { Pale green }\end{array}$} & October & $\begin{array}{l}\text { or Lapis Lazuli } \\
\text { Opal or Tourmaline }\end{array}$ & $\begin{array}{l}\text { Veep Dlue } \\
\text { Variegated }\end{array}$ \\
\hline & & & November & Topaz or Citrine & Yellow \\
\hline \multirow[t]{2}{*}{ June } & \multirow{2}{*}{$\begin{array}{l}\text { Pearl or Moonstone } \\
\text { (Feldspar) }\end{array}$} & \multirow{2}{*}{ Cream } & & (Quartz) & \\
\hline & & & December & Turquoise & Sky blue \\
\hline
\end{tabular}




\section{Organic gemstones}

The four organic gemstone groups listed below are highly prized for their beauty and rarity. However, they are not as durable as gemstones from minerals:

Amber (hardness: 2-2.5 Mohs)

A mixture of hydrocarbons

Specific gravity: 1.05-1.096

Hard fossil resin or sap of ancient pine trees. Usually amorphous (lacks crystalline structure). Sometimes mined, sometimes gathered on seashores.

Varies from transparent to semitransparent and generally from light yellow to dark brown, but can be orange, red, whitish, greenish-brown, blue, or violet. Can be dyed in any color.

Takes a fine polish. Used mainly in making beads or other ornaments.

Coral (hardness: $3.5-4$ Mohs)

Formed mainly of calcite (calcium carbonate) or conchiolin, a horny organic substance Specific gravity: $2.60-2.70$

Each coral polyp, a tiny marine animal that lives in enormous colonies, extracts calcium carbonate from the sea and exudes it to build a protective home around and above itself. Each generation of polyps dies in its protective home and each succeeding generation builds on top of its predecessor.

Gem coral ranges from semitranslucent to opaque and occurs in white, pink, orange, red, blue, violet, golden, and black. The black and golden corals are largely horny organic substances, not calcium carbonate.

The finest coral is used to make figurines, cameos, carvings, and beads.

Jet (hardness: 2.5-4 Mohs)

Carbon plus various hydrocarbon compounds

Specific gravity: $1.30-1.32$
This compact velvet-black coal takes a good polish and is often cut into beads, bracelets, and a wide range of decorative and useful objects.

\section{Pearl (hardness: 2.5-4.5 Mohs)}

Formed within a mollusk, such as an oyster, that deposits a substance called nacre around an irritant that entered the organism Specific gravity: 2.71

Pearl-bearing mollusks are found in both salt and fresh water. Salt-water pearls of gem quality are usually preferred for jewelry; they are produced almost entirely by the mollusk Pinctada. Fresh-water pearls are produced by various clams and mussels.

Natural pearls come in various shapes: round, pear, drop, egg, and others. They also come in various colors, such as white, cream, light rose, cream rose, black, gray, bronze, blue, dark blue, blue green, red, purple, yellow, and violet.

\section{Buyer beware}

Inexperienced buyers must take whatever steps are needed to ensure that gems they intend to purchase are exactly what the seller purports them to be and that they are being offered at a fair market price.

More and more synthetic gems-and inferior grades and cuts of natural gems - are being sold to unwary buyers by unscrupulous sellers. 
Since 1935, the mining of gemstones in the United States has been almost entirely a recreational activity of mineral collectors and hobbyists.

In recent years, very few individuals have derived their entire income from gemstones mined by themselves.

This is not to say that the proprietors of roadside rock shops buy all of their stock from others. Rock shops are abundant in areas of the United States that are rich in gem materials, and the shops tend to specialize in the local gem commodities, most of which the proprietors gather.

Rather than doing the mining themselves, owners of land that has a deposit of gemquality minerals sometimes charge hobbyists for the right to collect gemstones. For example, diamond in Arkansas, opal in Idaho, and agate in Oregon and Washington are mined by hobbyists under this "fee digging" arrangement.

However, the flow of money into the local economy by paying these small fees and by the purchase of gemstones is minor compared to the money the enthusiasts spend for lodging and other living expenses while visiting an area to dig for gemstones.

Several kinds of natural gemstones have been found in every State of the United States, but much larger deposits of the most precious kinds are found outside the United States.

The 1990 U.S. output of natural gemstones was primarily from Tennessee, California, Arizona, Arkansas, Montana, Nevada, and Maine.

An estimated 80,000 visitors found a total of 315 carats of diamonds in the Crater of Diamonds State Park in Arkansas. There were sizeable yields of freshwater pearls in Tennessee, turquoise in Arizona and Nevada, tourmaline in Maine, and tourmaline, kunzite, and garnet in California.
Gemstones: Value of U.S. production vs. imports, 1986 and 1989*

\begin{tabular}{|c|c|c|}
\hline Production & 1986 & 1989 \\
\hline Natural & $\$ 9.3$ million & $\$ 43.0$ million ${ }^{\star \star}$ \\
\hline \multirow[t]{2}{*}{ Synthetic } & 10.3 & 23.5 \\
\hline & $\$ 19.6$ & $\$ 66.5$ \\
\hline $\begin{array}{l}\text { Mine } \\
\text { employment }\end{array}$ & 300 & 800 \\
\hline $\begin{array}{l}\text { Imports for } \\
\text { consumption: }\end{array}$ & $\$ 4.18$ billion & $\$ 5.00$ billion \\
\hline $\begin{array}{l}\text { Apparent relianc } \\
\text { on imports } \\
\text { over exports }\end{array}$ & $99 \%$ & $98 \%$ \\
\hline
\end{tabular}

*Estimated. * Including freshwater pearls natural, and cultured. "**imports - exports + adjustments for Government and industry stock changes.

Source: Mineral Commodity Summaries, 1991 ,

U.S. Bureau of Mines.

U.S. production of commercial gems includes agate, beryl, freshwater pearl, garnet, jade, jasper, mother-of-pearl, opal, peridot, quartz, sapphire, tourmaline, and turquoise.

Except for the few gem diamonds found each year in Arkansas, U.S. diamond production is very low.

Yet exploration for diamonds continues in Alaska, Colorado, Michigan, Minnesota, Wisconsin, and Wyoming. A diamond mining project at the Crater of Diamonds State Park in Arkansas is still being evaluated by the State.

World diamond reserves are estimated to be about 300 million carats, including near-gem materials but not diamonds of abrasive quality.

Most of the reserves are in southern Africa, Siberia, and western Australia. It is difficult to estimate reserves because the value of a given deposit varies with the market for the gems. 


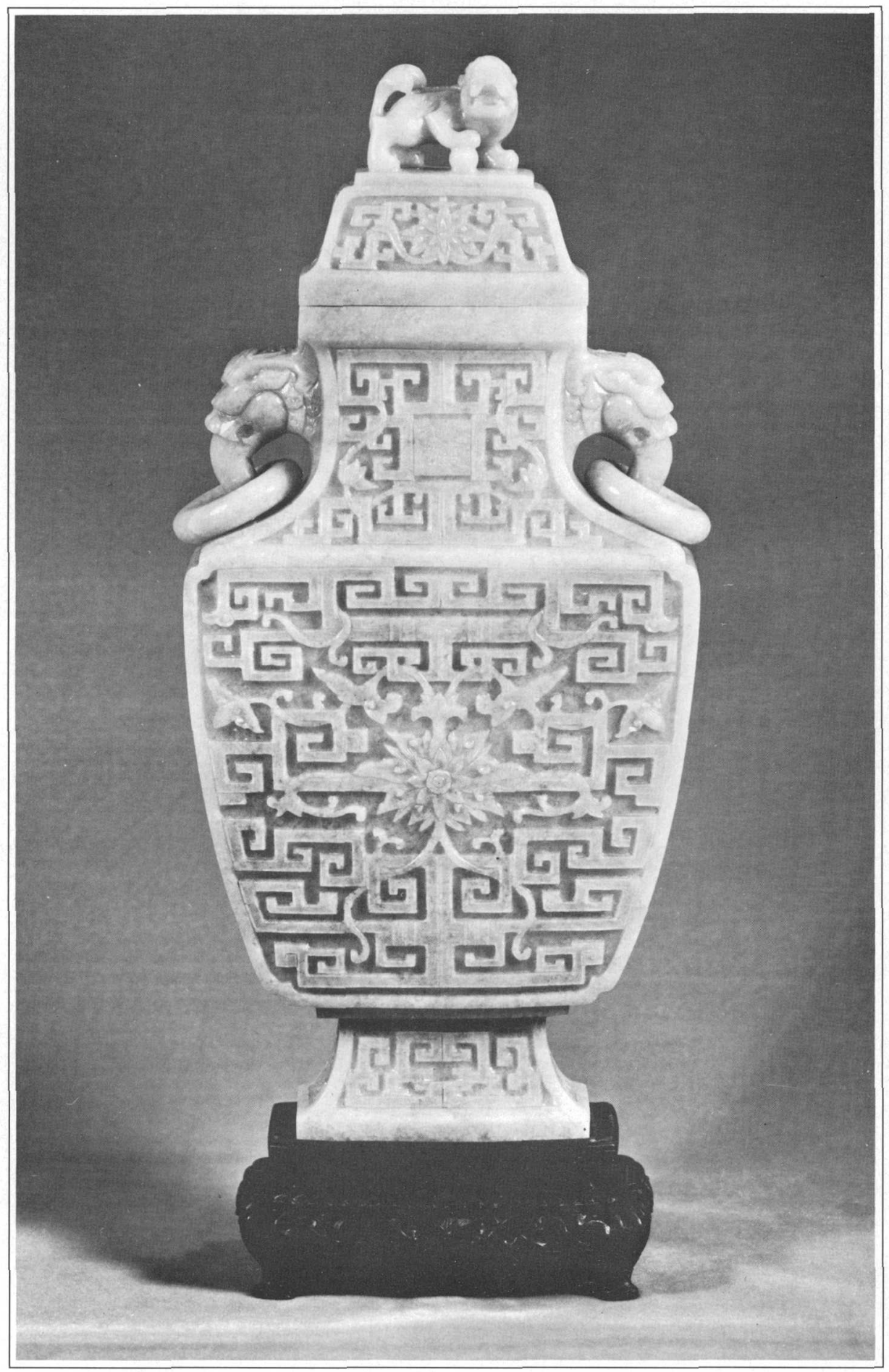

Jade nephrite, China. 


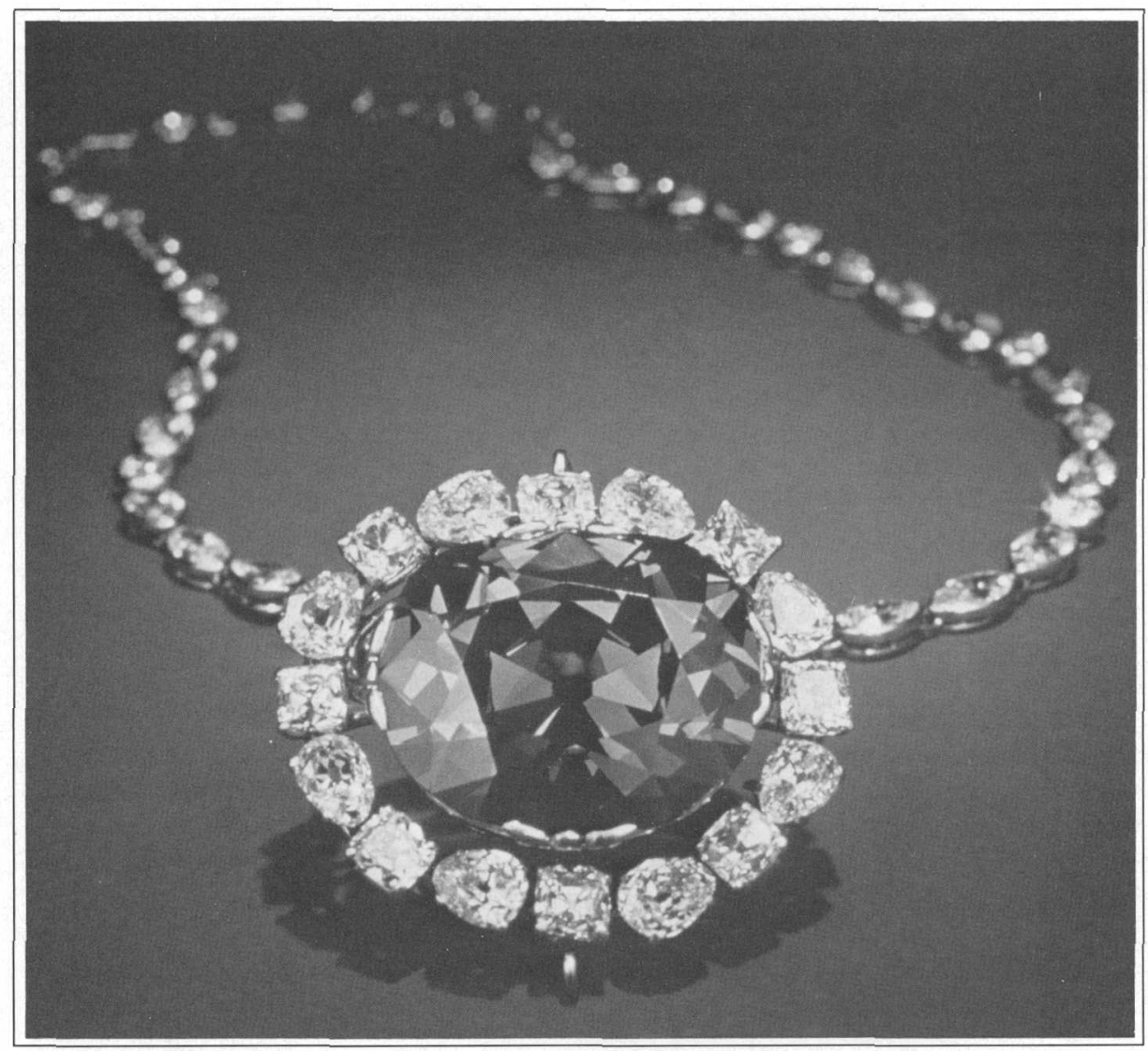

The Hope Diamond, India.

\section{Chemical formulas of gemstones}

\begin{tabular}{|c|c|c|c|}
\hline $\begin{array}{l}\text { Beryl } \\
\text { Chrysoberyl } \\
\text { Coral }\end{array}$ & $\begin{array}{l}\mathrm{Be}_{3} \mathrm{Al}_{2} \mathrm{Si}_{6} \mathrm{O}_{18} \\
\mathrm{BeAl}_{2} \mathrm{O}_{4} \\
\mathrm{CaCO}_{3}\end{array}$ & Jade & $\begin{array}{l}\text { Nephrite } \\
-\mathrm{Ca}_{2}(\mathrm{Mg}, \mathrm{Fe})_{5}\left(\mathrm{Si}_{8} \mathrm{O}_{22}\right)(\mathrm{OH})_{2} \\
\text { Jadeite- } \mathrm{NaAl}\left(\mathrm{Si}_{2} \mathrm{O}_{6}\right)\end{array}$ \\
\hline $\begin{array}{l}\text { Corundum } \\
\text { Diamond }\end{array}$ & $\begin{array}{l}\mathrm{Al}_{2} \mathrm{O}_{3} \\
\mathrm{C}\end{array}$ & Lapis lazuli & $\begin{array}{l}\text { Lazurite- }(\mathrm{Na}, \mathrm{Ca})_{8}\left(\mathrm{AlSiO}_{4}\right)_{6} \\
\left(\mathrm{SO}_{4}, \mathrm{~S}, \mathrm{Cl}\right)_{2}\end{array}$ \\
\hline Feldspar & $\begin{array}{l}\text { Plagioclase Series: } \\
\text { (Na,Ca)Al(Al, } \mathrm{Si}) \mathrm{Si}_{2} \mathrm{O}_{8} \\
\text { Alkali Feldspar } \mathrm{Group} \\
\text { Mixtures of Orthoclase } \\
-\mathrm{KAISi}_{3} \mathrm{O}_{8} \text { and Albite } \\
-\mathrm{NaAlSi}_{3} \mathrm{O}_{8}\end{array}$ & $\begin{array}{l}\text { Opal } \\
\text { Peridot } \\
\text { Quartz } \\
\text { Spinel } \\
\text { Topaz }\end{array}$ & $\begin{array}{l}\text { Hydrated Silica } \\
-\mathrm{SiO}_{2} \cdot n \mathrm{H}_{2} \mathrm{O} \\
(\mathrm{Mg}, \mathrm{Fe})_{2}\left(\mathrm{SiO}_{4}\right) \\
\mathrm{SiO}_{2} \\
\mathrm{MgAl}_{2} \mathrm{O}_{4} \\
\mathrm{Al}_{2} \mathrm{SiO}_{4}(\mathrm{~F}, \mathrm{OH})_{2}\end{array}$ \\
\hline Garnet & $\begin{array}{l}\text { Almadine- } \mathrm{Fe}_{3} \mathrm{Al}_{2}\left(\mathrm{SiO}_{4}\right)_{3} \\
\text { Andradite- }-\mathrm{Ca}_{3} \mathrm{Fe}_{2}\left(\mathrm{SiO}_{4}\right)_{3} \\
\text { Grossular- } \mathrm{Ca}_{3} \mathrm{Al}_{2}\left(\mathrm{SiO}_{4}\right)_{3} \\
\text { Pyrope- }-\mathrm{Mg}_{3} \mathrm{Al}_{2}\left(\mathrm{SiO}_{4}\right)_{3}\end{array}$ & Tourmaline & $\begin{array}{l}\mathrm{XY}_{3} \mathrm{Al}_{6}\left(\mathrm{BO}_{3}\right)_{3}\left(\mathrm{Si}_{6} \mathrm{O}_{18}\right)\left(\mathrm{OH}_{4}\right) \\
{[\mathrm{X} \text { is usually } \mathrm{Na} \text { but may }} \\
\text { be replaced by } \mathrm{Ca} ; \mathrm{Y} \text { is } \\
\text { one of several metal ions] }\end{array}$ \\
\hline & Spessartine- $-\mathrm{Mn}_{3} \mathrm{Al}_{2}\left(\mathrm{SiO}_{4}\right)_{3}$ & Turquoise & $\mathrm{CuAl}_{6}\left(\mathrm{PO}_{4}\right)_{4}(\mathrm{OH})_{8} \cdot 4 \mathrm{H}_{2} \mathrm{O}$ \\
\hline & Uvarovite- $-\mathrm{Ca}_{3} \mathrm{Cr}_{2}\left(\mathrm{SiO}_{4}\right)_{3}$ & Zircon & $\mathrm{ZrSiO}_{4}$ \\
\hline
\end{tabular}




\section{Some ways to contact a local rock, mineral, or gem club}

If you have access to the most recent April Buyer's Guide issue of the Lapidary Journal magazine, scan its lists of gem and mineral clubs in the United States and other countries. (The address of the Lapidary Journal is given in the list of journals cited below.)

Talk to a member of the geology or earth science department of your local college or university.

Talk to a member of the science department of your local high school.

Write to the-

Eastern Federation of Mineralogical and Lapidary Societies, Box 10119, Alexandria, VA 22310-0119

or the

Midwest Federation of Mineralogical and Geological Societies

306 Somonauk

Park Forest, IL 60466

Check the phone book for your nearest rock and mineral shop and talk to the owners.

\section{Role of the U.S. Geological Survey (USGS)}

The USGS reports deposits that seem likely to contain gemstones. It is not a function of the USGS to exploit such resources.

USGS geologists perform continuing research on kimberlites, the initial source of diamonds. Not all kimberlites are diamondbearing, and some of the research is directed to learning what indications you look for during exploration to distinguish fertile from barren kimberlite. USGS geologists are compiling a U.S. map showing the locations of known kimberlites.

\section{Selected general references}

A trip to your local library is the best first step toward understanding gemstones and toward planning a trip to gem and rock shops or to places where you may be able to collect gemstones.

A list of Selected references on rocks, minerals, and gemstones is compiled and updated every two years by the USGS Geologic Inquiries Group, 907 National Center, Reston, VA 22092; (703) 648-4383. The list has three sections: selected guides for rockhounds and hobbyists, general references for all ages, elementary school to adult, and periodicals.

The guides in Section I tell about equipment needed for collecting, etiquette of collecting, map reading, organizing a collection, collecting localities by States, mineral societies, mineral show dates and locations, and rock, mineral, and fossil dealers.

The references below focus mainly on natural gemstones and the gems made from them rather than on synthetic gemstones, rocks, or other nongem minerals.

\section{Minerals Yearbook}

The relatively few pages on gemstones in the multivolume Minerals Yearbook provide data on sources, kinds, and volume of domestic production, domestic consumption, prices, and foreign trade. This U.S. Bureau of Mines yearbook is in the reference sections of many major libraries. It can be purchased from the Superintendent of Documents, U.S. Government Printing Office, Washington, DC 20402. 


\section{Books}

Gemology, Cornelius S. Hurlbut Jr. and Robert C. Kammerling: John Wiley \& Sons, New York, 1991, 2nd ed.

Gemstones and Their Origins, Peter C. Keller: Van Nostrand Reinhold, 1990.

Color Encyclopedia of Gemstones, Joel Arem: Van Nostrand Reinhold, New York, 1987, 2nd ed., 68 p.

Gemstones for Everyman, B.W. Anderson: Van Nostrand Reinhold, 1976, 268 p.

Gems and Precious Stones, Curzio Cipriani and Alessandro Boreli; Valerie Palmer, translator: Kennie Lyman, U.S. editor: Simon and Schuster, New York, 1986, 384 p.

Gem and Crystal Treasures, Peter Bancroft: Mineralogical Record, Carson City, NV, $1984,488 \mathrm{p}$.

Planet Earth-Gemstones, Paul O'Neil and the editors of Time-Life Books: Time-Life Books, Arlington, VA, 1983, $176 \mathrm{p}$.

Gemstones of the World, Walter Schumann (translated by Evelyne Stern): Sterling, New York, 1984, 256 p.

Gems \& Crystals from the American Museum of Natural History: An illustrated guide to the history, lore, and properties of the gems and minerals of one of the world's greatest collections, Anna S. Sofiandes and George E. Harlow: Simon \& Schuster, New York, 1990, 208 p.

The Gem Collection (Treasures in the Smithsonian Series No.1), P.E. Desautels: Smithsonian Institution, Washington, 1983, 77 p.
Gemstones of North America, John Sinkankas: D. Van Nostrand Company, Inc., Princeton, 1959, 675 p.

Gems and Precious Stones of North America-A popular description of their occurrence, value, history, archeology, and of collections in which they exist, G.F. Kunz: Dover Publishing, New York, 1968 (reprint of a classic work dated 1892), 367 p.

Emerald and Other Beryls, John Sinkankas: Chilton Way, Radnor, PA, 1981, 665 p.

Handbook of Gem Identification, R.T. Liddicoat Jr.: Gemological Institute of America, Santa Monica, CA, 1981 (11th ed.), $450 \mathrm{p}$.

Field Collecting Gemstones and Minerals, John Sinkankas: Geoscience Press, Prescott, AZ, 1988, 2nd ed., 397 p.

Prospecting for Gemstones and Minerals [Formerly Gemstones and Minerals: How and Where to Find Them], John Sinkankas: Van Nostrand Reinhold, New York, 1970, 2nd ed., 397 p.

Mineral \& Gem Trails of Delaware, Virginia, Maryland, North Carolina, Ed and Bert Sloan: EDSCO, Box 79, Oneonta, NY 13820, 1978, 52 p.

Gem Testing, B.W. Anderson: Butterworth, Woburn, MA, 1980, 9th ed., 384 p.

Gemology, C.S. Hurlbut Jr. and G.S. Switzer: Wiley, New York, 1979, 596 p.

Gems and Jewelry, Joel Arem: Bantam Books, New York, 1975, 159 p.

Gem Cutting: A Lapidary's Manual, John Sinkankas: Van Nostrand Reinhold, New York, 1962, 2nd ed., 297 p. 


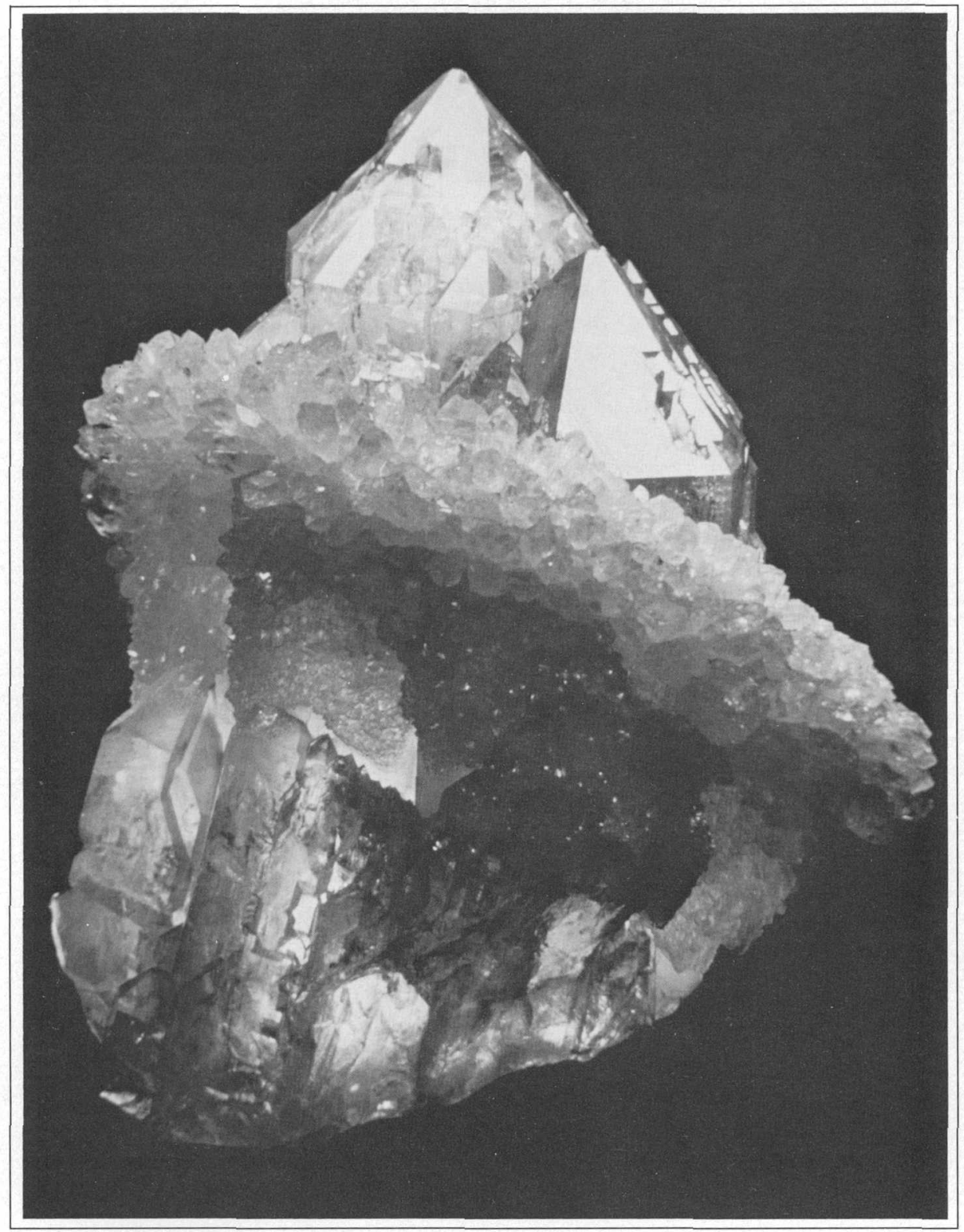

Lavender-hued rose quartz, Brazil. 
Splendid Stones. This National Geographic

Gems and Gemology (quarterly). Articles on gemstone localities, identification, and history. Includes annual index, lab notes, book reviews, and gemological abstracts. Published by the Gemological Institute of America, 1660 Stewart Street, Santa Monica, CA 90404.

Lapidary Journal (monthly). Articles on gemstones, locality information, expeditions to find sources of gemstones, gemcraft, club news, show news, product news, and book reviews. Published by the Lapidary Journal, Devon Office Center, Suite 201, 60 Chestnut Avenue, Devon, PA 19333-1312.

Rocks \& Minerals (bimonthly). Features articles of interest to students of mineralogy, geology, and paleontology. Includes articles about gemstone localities. Regularly lists announcements of hundreds of mineral, rock, and gem shows (local, State, national, Canadian, and European). Includes media reviews, museum notes and announcements, and classified ads. Published by Heldref Publications, 4000 Albermarle Street, NW., Washington, DC 20016.

Jewelers' Book Club_Catalog (annual). Catalog of more than 550 jewelry-related publications from more than 250 publishers. Includes video- and audio-cassettes and book reviews. Jewelers' Book Club-News (quarterly) informs members of new titles and provides book reviews. Published by the Jewelers Book Club, Chilton Way, Radnor, PA 19089.

\section{Videocassettes}

Gemstones of America (60 minutes), Smithsonian Institution, 1991, can be ordered for $\$ 29.95$ from the Museum Shop, Attention: Mail Order Clerk, National Museum of Natural History, 10th Street and Constitution Avenue, NW., Washington, DC 20560; (202) 357-1535.
Society special details the evolution from raw material to cut and polished gem, outlines many of the steps involved in marketing gemstones, and examines some of the world's most famous jewelry collections. It can be ordered for $\$ 95$ from the National Geographic Society, 17th and M Streets NW., Washington, DC 20036.

\section{Acknowledgments}

The U.S. Geological Survey is grateful to the following individuals for their assistance:

Harvey E. Belkin, Geologist, Geological Survey, U.S. Department of the Interior, Reston, VA.

Gordon T. Austin, "Gem Stones," Mineral Commodity Summaries 1991, Bureau of Mines, U.S. Department of the Interior, Washington, DC.

Robert E. Thaden, "Gem Stones," in United States Mineral Resources, Geological Survey Professional Paper 820, U.S. Government Printing Office, Washington, 1973 , p. $247-250$.

Jane Jenness, Minerals Information Office, U.S. Geological Survey, Washington, DC.

\section{Photographs}

All photographs are courtesy of The Smithsonian Institution. 


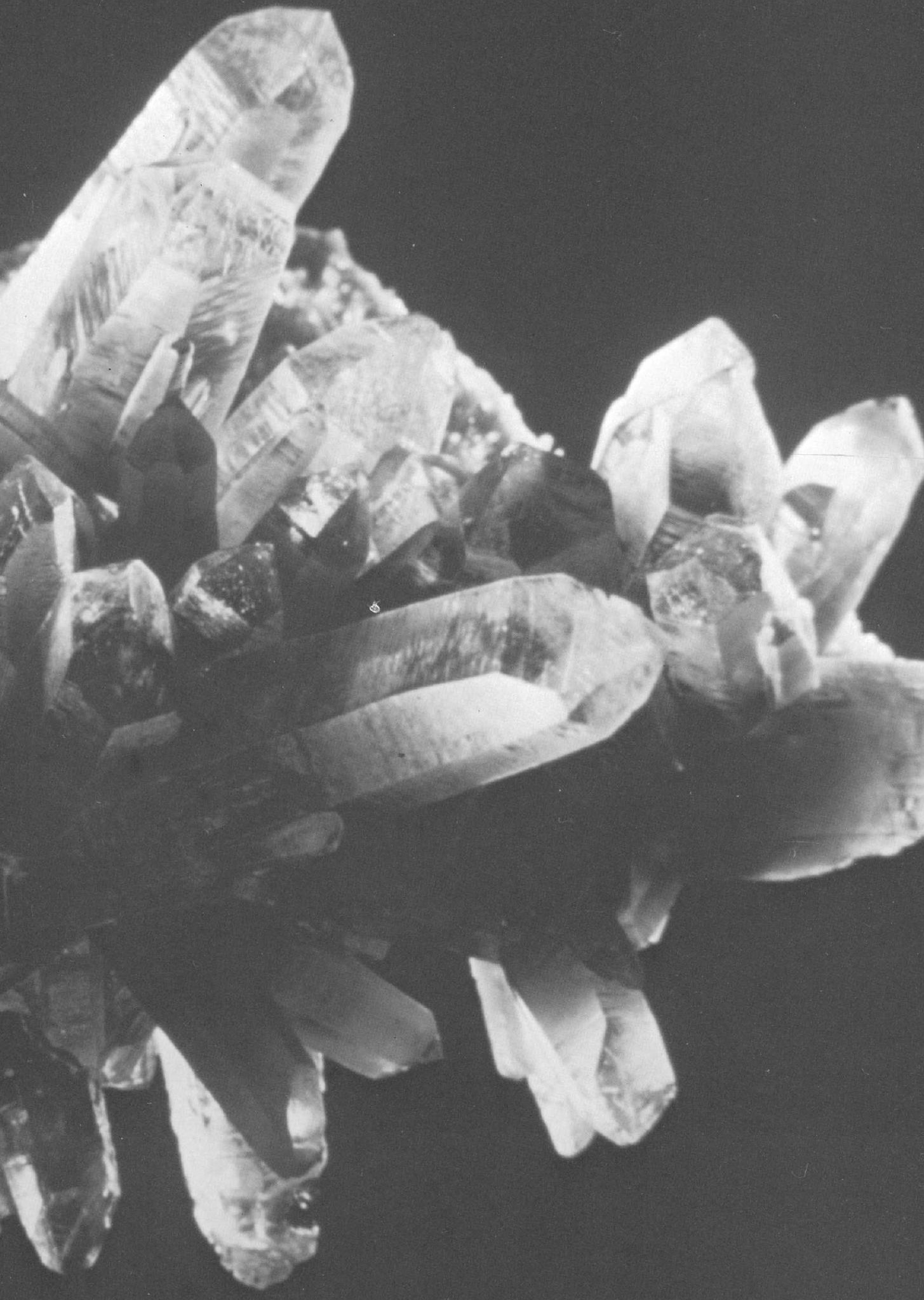


